\title{
Komoditas Tembakau Besuki Na-Oogst dalam Perspektif Pembangunan Berkelanjutan di Kabupaten Jember
}

\section{Besuki Na-Oogst Tobacco Commodity in the Perspective of Sustainable Development in Jember Regency}

\author{
Rhamanda Try Muktianto*, Herman Cahyo Diartho
}

Jurusan Ilmu Ekonomi dan Studi Pembangunan, Fakultas Ekonomi dan Bisnis, Universitas Jember

Corresponding author: rhamandatry@gmail.com

\begin{abstract}
Tobacco commodities Besuki Na-Oogst in Jember regency of production continue to decrease. The decline in tobacco production Besuki Na-Oogst caused by erratic weather, high rainfall, volcanic ash mounts roar. The purpose of this research to analyze the sustainability status of tobacco commodities Besuki Na-Oogst seen from the ecological, economic, and social dimension. The method of analysis used in this research is descriptive method and RAP-Tobacco analysis with Multidimensional scaling method. The result of the research shows that the agribusiness system of tobacco commodities Besuki Na-Oogst is still not related, the relationship between subsystems of supply of production facilities, cultivation subsystem or farming and supporting service subsystem still not close. The sustainability status of multi-dimensional Na-Oogst tobacco commodities including ecological, economic, and social dimensions shows that tobacco Besuki Na-Oogst commodities are on a sustainable status with an index value of 58.27 which means the index values are all dimensions including: ecological, economic dimension, and social effect on the sustainability status of tobacco commodities besuki Na-Oogst and most farmers in Wuluhan sub-district still want to grow besuki Na-Oogst tobacco.
\end{abstract}

Keywords: Besuki Na-Oogst tobacco, status of sustainability, RAP-tobacco

Cite this as: Muktianto, R. T., \& Diartho, H. C. 2018. Komoditas Tembakau Besuki Na-Oogst dalam Perspektif Pembangunan Berkelanjutan di Kabupaten Jember. Caraka Tani: Journal of Sustainable Agriculture. 33(2), 115125. doi: http://dx.doi.org/10.20961/carakatani.v33i2.20598

\section{PENDAHULUAN}

Negara Indonesia merupakan suatu negara yang memiliki wilayah dengan lahan petanian yang sangat luas dan penduduknya sebagian besar bermata pencarian sebagai petani. Sektor pertanian di Indonesia memberikan kontribusi yang sangat besar terhadap perekonomian daerah dan nasional antara lain, dalam bentuk penyerapan tenaga kerja, pemasok penyediaan bahan pangan, penyediaan bahan baku untuk pabrik industri dan meningkatkan pendapatan pada masyarakat sekitar. Sektor pertanian di Indonesia merupakan sektor yang menjadi andalan dalam mengembangkan perekonomian di pedesaan. Pengembangan potensi yang ada pada sektor pertanian khususnya subsektor perkebunan merupakan bagian dari pembangunan nasional yang harus terus bersifat berkelanjutan.

Pembangunan berkelanjutan merupakan pembangunan yang mewujudkan (memenuhi) kebutuhan hidup saat ini tanpa mengurangi kemampuan generasi mendatang untuk mewujudkan kebutuhan hidupnya. Pelaksanaan pembangunan ekonomi yang berkeadilan sosial dilakukan tanpa mengorbankan lingkungan, sehingga pembangunan yang dilaksanakan saat ini harus sudah memikirkan pula kebutuhan hidup generasi berikutnya (Rivai dan Anugrah, 2011).

\footnotetext{
* Received for publication April 21, 2018

Accepted after corrections September 21, 2018
} 
Sasaran Pembangungan berkelanjutan mencakup upaya untuk pemerataan manfaat hasilhasil pembangunan antar generasi atau pengamanan terhadap kelestarian sumber daya alam dan lingkungan hidup, pemanfaatan dan pengelolaan sumberdaya alam yang digunakan untuk kepentingan mengejar pertumbuhan ekonomi, mempertahankan kesejahteraan masyarakat yang berkelanjutan, mempertahankan manfaat pembangunan, menjaga mutu ataupun kualitas kehidupan manusia antar generasi (Rahadian, 2016).

Subsektor perkebunan merupakan bagian dari sektor pertanian yang memiliki peranan penting dalam perekonomian daerah dan nasional. Salah satu komoditas perkebunan di Indonesia yang memiliki komoditas potensial serta memberikan kontribusi yang cukup besar terhadap pendapatan nasional dan daerah adalah komoditas tembakau. Tanaman tembakau (Nicotiana tabacum L.) pertama kali masuk Indonesia kira-kira tahun 1630, kemudian berkembang ke berbagai daerah di Indonesia. Tembakau merupakan tanaman tropis, meskipun demikian daerah penanamannya cukup luas, mulai dari daerah panas seperti di Indonesia sampai pada daerah yang beriklim dingin seperti Norwegia. Tembakau dapat ditanam pada dataran tinggi maupun rendah. Perbedaan ketinggian tempat mengakibatkan perbedaan kualitas daun tembakau (Suyana et al., 2010).

Tembakau merupakan salah satu komoditas yang bisa memberikan manfaat ekonomi, dan manfaat sosial yang bisa di rasakan oleh kalangan masyarakat banyak. Peran tembakau terhadap perekonomian Indonesia dapat ditunjukkan dari besarnya cukai yang disumbangkan sebagai penerimaan negara dan banyaknya tenaga kerja yang terserap baik dalam tahap penanaman dan pengolahan tembakau sebelum diekspor atau dibuat rokok, maupun pada tahap pembuatan rokok (Santoso, 2013). Selain itu Tembakau dianggap sebagai salah satu tanaman perkebunan komersial yang memiliki harapan pertanian tinggi keuntungan. Kabupaten Jember adalah salah satu daerah di Provinsi Jawa Timur yang diakui sebagai pusat produksi tembakau. Varietas utama tembakau yang dapat ditanam di Kabupaten Jember adalah Besuki Na-Oogst Tembakau. Tembakau Besuki Na-Oogst memberikan keuntungan yang tinggi bila dibandingkan dengan komoditas lain (Pratama et al., 2018).

Table 1. Percent Distribution of Gross Regional Domestic Product in the Agriculture Sector of Jember $2012-2015$

\begin{tabular}{clcccc}
\hline \multirow{2}{*}{ No. } & \multirow{2}{*}{ Sektor Pertanian } & \multicolumn{4}{c}{ Kontribusi Sektor Pertanian Terhadap PDRB (\%) } \\
\cline { 3 - 6 } & & 2012 & 2013 & 2014 & 2015 \\
\hline 1. & Tanaman Pangan & 8,44 & 8,41 & 8,09 & 8,02 \\
2. & Hortikultura & 2,97 & 2,86 & 2,76 & 2,74 \\
3. & Perkebunan & 11,08 & 10,74 & 10,57 & 10,59 \\
4. & Peternakan & 5,38 & 5,33 & 5,17 & 4,92 \\
5. & Kehutanan & 1,02 & 0,97 & 0,94 & 0,92 \\
6. & Perikanan & 2,07 & 2,01 & 2,01 & 2,03 \\
\hline
\end{tabular}

Sumber : BPS Kabupaten Jember, 2013, 2014, 2015, 2016

Table 1. menunjukkan bahwa sektor pertanian yang memiliki kontribusi yang sangat tinggi terhadap PDRB Kabupaten Jember adalah subsektor perkebunan, sedangkan untuk subsektor pertanian yang lain diantaranya seperti tanaman pangan, peternakan, hortikultura, Perikanan dan Kehutanan memiliki kontribusi yang cukup untuk menunjang perekonomian Kabupaten Jember.

Berdasarkan penggunaannya, tembakau di Indonesia digolongkan menjadi empat kelompok: (1) Tembakau cerutu, (2) Kretek cigaret tembakau, (3) tembakau rokok RYO, dan (4) Kenyal tembakau. Tobaccos dibagi menjadi dua kelompok berdasarkan periode waktu tanam, yaitu (1) Voor-Oogst dan (2) Na-Oogst. Tembakau Voor-Oogst merupakan tembakau yang ditanam di akhir musim hujan dan panen di musim kemarau. Sedangkan, tembakau Besuki $\mathrm{Na}$-Oogst adalah tembakau yang ditanam di akhir musim kemarau dan dipanen pada waktu musim hujan (Djajadi, 2015). Tembakau Voor-Oogst merupakan tembakau yang digunakan sebagai bahan baku rokok kretek sedangkan Tembakau Besuki Na-Oogst digunakan sebagai bahan baku rokok cerutu (Qoriah dan Meliczek, 2006).

Kabupaten Jember merupakan salah satu daerah yang memiliki potensi tinggi pada 
subsektor perkebunan terutama pada komoditas tembakau Besuki Na-Oogst. Komoditas tembakau Besuki Na-Oogst sudah menjadi icon Kabupaten
Jember. Tetapi dalam kurun 4 tahun terakhir produksi tembakau Besuki Na-Oogst mengalami penurunan secara drastis.

Table 2. Tobacco Production in Jember Regency

\begin{tabular}{cccccc}
\hline \multirow{2}{*}{ No. } & \multirow{2}{*}{ Jenis Tembakau } & \multicolumn{4}{c}{ Tahun } \\
\cline { 3 - 6 } & & 2012 & 2013 & 2014 & 2015 \\
\hline 1. & Na-Oogst & $102.770,00$ & $79.758,00$ & $78.896,60$ & $45.697,98$ \\
2. & Kasturi & $177.834,00$ & $119.782,00$ & $145.275,40$ & $161.867,68$ \\
3. & Rajang & $19.335,50$ & $6.214,50$ & $14.103,80$ & $11.113,30$ \\
4. & White Burley & $3.424,50$ & $3.886,00$ & $5.029,00$ & $2.715,50$ \\
\hline
\end{tabular}

Sumber : BPS Kabupaten Jember, 2013, 2014, 2015, 2016

Table 2. menunjukkan bahwa produksi dengan jenis tembakau Besuki Na-Oogst mengalami penurunan yang sangat drastis dalam kurun waktu 4 tahun terakhir hal ini disebabkan oleh cuaca yang tidak menentu, tingginya curah hujan, abu vulkanik Gunung Raung dan minimnya penyediaan sarana produksi dan harga dari beberapa input produksi juga belum bisa dijangkau oleh petani sehingga petani tidak lagi menanam komoditas Besuki Na-Oogst dan beralih pada komoditas yang lain. Hal ini akan berdampak terhadap keberlanjutan komoditas tembakau Besuki Na-Oogst (Sari et al., 2017). Oleh karena itu sangat penting untuk menganalisis status keberlanjutan komoditas tembakau Besuki $\mathrm{Na}$-Oogst dilihat dari dimensi ekologi, ekonomi dan sosial.

Dimensi ekologi merupakan dimensi yang digunakan untuk melihat dan mengatasi penurunan terhadap kualitas tanah di lahan pertanian tembakau Besuki Na-Oogst. Dimensi ekonomi merupakan dimensi yang digunakan untuk melihat keuntungan petani dalam menanam tembakau Besuki Na-Oogst serta kontribusi komoditas tembakau Besuki Na-Oogst terhadap daerah. Sedangkan untuk Dimensi sosial merupakan dimensi yang digunakan untuk melihat kondisi sosial masyarakat yang riil serta budaya dan tradisi yang ada pada masyarakat tersebut. Berdasarkan latar belakang tersebut peneliti perlu melakukan identifikasi terhadap status keberlanjutan komoditas tembakau Besuki $\mathrm{Na}$-Oogst dilihat dari dimensi ekologi, ekonomi dan sosial. Rumusan masalah dalam penelitian ini bagaimana status keberlanjutan komoditas tembakau Besuki Na-Oogst dilihat dari dimensi ekologi, ekonomi, dan sosial.

\section{METODE PENELITIAN}

Metode dasar penelitian yang digunakan adalah metode deskriptif kuantitatif. Metode penentuan lokasi penelitian dilakukan secara purposive (sengaja). Daerah yang dipilih sebagai objek penelitian adalah Kabupaten Jember dimana Kabupaten Jember merupakan penghasil tembakau Besuki Na-Oogst yang cukup besar. Pengambilan sampel dalam penelitian ini dilakukan di Kecamatan Wuluhan, hal tersebut diambil dengan dasar karena Kecamatan Wuluhan memiliki produktifitas tembakau Besuki $\mathrm{Na}$ Oogst tertinggi di Kabupaten Jember.

Metode pengambilan sampel yang digunakan dalam penelitian ini adalah teknik probability sampling dengan menggunakan proportionate stratified random sampling. Teknik probability sampling merupakan teknik pengambilan sampel yang memberikan peluang yang sama bagi setiap unsur anggota populasi untuk dipilih menjadi anggota sampel.

Sedangkan teknik proportionate stratified random sampling adalah teknik yang digunakan bila populasi mempunyai anggota atau unsur yang tidak homogen dan berstrata secara proporsional. Populasi yang diambil adalah petani yang menanam padi dan juga tembakau Besuki $\mathrm{Na}$ Oogst di Kecamatan Wuluhan Kabupaten Jember sebanyak 8.916 petani. Komoditas utama didaerah penelitian adalah padi, sehingga populasi yang digunakan petani yang menanam padi dan juga menanam tembakau Besuki Na-Oogst. Pengambilan sampel didasarkan pada luas lahan yang dimiliki, yaitu kelompok petani kecil dengan luas lahan $>0,15 \leq 0,5$ ha; kelompok petani sedang dengan luas lahan $>0,51 \leq 1$ ha; dan 
kelompok petani besar dengan luas lahan $>1$ ha. Untuk menentukan ukuran sampel ditarik secara random dari masing-masing wilayah digunakan formulasi slovin (Umar, 2003).

$$
n=\frac{N}{1+N e^{2}}
$$

Keterangan:

$$
\begin{array}{ll}
\mathrm{N} & =\text { jumlah populasi } \\
\mathrm{n} & =\text { jumlah sampel } \\
\mathrm{e} & =\text { persen kelonggaran penelitian }
\end{array}
$$

Jadi, jumlah sampel penelitian dapat dihitung sebagai berikut:

$$
\begin{gathered}
\mathrm{n}=\frac{7886}{1+(7886 \times 0,1)^{2}} \\
\mathrm{n}=98,74
\end{gathered}
$$

Jumlah populasi yang mencapai 7886 orang dengan tingkat kesalahan (10\%), maka sempel yang diperoleh berjumlah 99 orang (setelah pembulatan). Sampel sebesar 99 diambil dari seluruh desa yang berada di Kecamatan Wuluhan.

Jenis data yang digunakan dalam penelitian ini adalah data primer yang bersifat desktiptif kuantitatif yaitu data yang diperoleh dari petani yang menanam tembakau Besuki Na-Oogst. Metode analisis data yang digunakan dalam penelitian ini menggunakan analisis RAP-Fish (Rapid Appraissal for Fisheries) dengan metode Multidimensional scaling (MDS) yang dimodifikasi menjadi RAP-Tobacco. (Rapid Appraissal for Tobacco).

Metode Rapfish sebelumnya digunakan untuk menilai keberlanjutan perikanan tangkap (Fauzi, 2004). Dalam perkembangannya metode ini digunakan untuk berbagai kasus keberlanjutan lainnya. Adapun tahapan analisis RAP-Fish (Rapid Appraissal for Fisheries) dengan metode Multidimensional scaling (MDS) adalah (Thamrin, Sutjahjo, Herison, \& Sabiham, 2007) :

a. langkah pertama adalah me-review, mengidentifikasi, dan mendefinisikan atribut dimensi ekonomi, lingkungan, dan sosial. Atribut dari tiap-tiap dimensi berikutnya ditentukan berdasarkan penetapan awal juga dari hasil wawancara dan observasi;

b. langkah kedua melakukan penilaian (scoring) didasarkan pada hasil pengamatan lapangan. Penilaian (scoring) penyusunan indeks dan status keberlanjutan pada wilayah penelitian berdasarkan skor yang diperoleh. Penilaian yang dilakukan oleh petani tembakau Besuki $\mathrm{Na}$-Oogst dalam setiap atribut menggunakan rentang skor berkisar antara 0-3, yang diartikan dari buruk sampai baik atau sebaliknya, tergantung kondisi masingmasing.

c. langkah ketiga adalah hasil pemberian skor yang telah dilakukan oleh 99 petani tembakau Besuki Na-Oogst kemudian dianalisis dengan menggunakan Analisis Rap-Tobacco Ordination dengan menggunakan teknik Multidimensional scaling (MDS), untuk menentukan posisi status keberlanjutan tembakau Besuki Na-Oogst di Kabupaten Jember pada setiap dimensi maupun multidimensi yang dinyatakan dalam nilai indeks keberlanjutan yang terletak antara 0 100.

Table 3. Sustainability Status Categories for Besuki Na-Oogst tobacco based on Index Value Results of Rap-Tobacco Ordination Analysis using Multidimensional scaling (MDS) techniques

\begin{tabular}{cc}
\hline Nilai Indeks & Status Keberlanjutan \\
\hline $0,00-25,00$ & Buruk (Tidak Berkelanjutan) \\
$25,01-50,00$ & Kurang (Kurang \\
& Berkelanjutan) \\
$50,01-75,00$ & Cukup (Cukup \\
& Berkelanjutan) \\
$75,01-100,00$ & Baik (Sangat Berkelanjutan \\
\hline
\end{tabular}

Sumber : Thamrin et al., 2007

Penelitian ini dianalisis dengan menggunakan aplikasi Rapfish yang terpasang pada modus addins pada aplikasi microsoft excel. Terdapat tiga hal running program aplikasi, yaitu Run Rapfish, Run Leverage, dan Run Monte Carlo (Thamrin et al., 2007).

a. Run Rapfish

Program aplikasi Run rapfish yang dimodifikasi menjadi Rap-Tobacco digunakan untuk menentukan posisi yang keberlanjutan disetiap dimensi yang dikaji. Aplikasi ini menerapkan dua titik acuan, yaitu titik "baik" (good) dan titik "buruk" (bad). Titik acuan ini bertujuan untuk membantu penetapan posisi keberlanjutan yang akan sulit mengingat terdapatnya banyak atribut pada dimensi yang ada (Thamrin et al., 2007). 
Menurut Kavanagh dan Pitcher (2004), nilai stress yang dapat diperbolehkan adalah apabila berada dibawah nilai 0,25 (menunjukkan hasil analisis sudah cukup baik). Sedangkan nilai $\mathrm{R}^{2}$ diharapkan mendekati nilai $1(100 \%)$ yang berarti bahwa atribut-atribut yang terpilih saat ini dapat menjelaskan mendekati $100 \%$ dari model yang ada.

b. Run Leverage

Analisis Laverage digunakan untuk mengetahui atribut atribut yang sensitif, ataupun perbaikan terhadap atribut yang sensitif untuk meningkatkan status keberlanjutan komoditas tembakau Besuki $\mathrm{Na}$ Oogst. Penentuan atribut yang sensitif dilakukan berdasarkan urutan prioritasnya pada hasil analisis Laverage dengan melihat bentuk perubahan root mean square (RMS) ordinasi pada sumbu X. Semakin besar nilai perubahan RMS, maka semakin besar pula peranan atribut tersebut dalam peningkatan status keberlanjutan, atau dengan kata lain, semakin sensitif atribut tersebut dalam status keberlanjutan komoditas tembakau Besuki $\mathrm{Na}$ Oogst di lokasi penelitian (Thamrin et al., 2007). Atribut sensitif merupakan atribut yang berperan bagi status keberlanjutan pada dimensi yang akan dikaji, dimana atribut ini mampu mendorong dan menghambat status keberlanjutan dari komoditas tembakau Besuki Na-Oogst pada dimensi ekologi. Atribut sensitif bisa dilihat dari nilai Root mean Square (RMS), apabila nilai RMS $\geq 2 \%$ maka atribut tersebut masuk dalam kategori sensitif (Lestari et al., 2015).

c. Run Monte Carlo

Analisis Monte Carlo digunakan untuk menduga pengaruh atau kesalahan dalam proses analisis yang dilakukan, pada tingkat kepercayaan $95 \%$. Hasil analisis dinyatakan dalam bentuk nilai indeks Monte Carlo, yang selanjutnya dibedakan dengan nilai indeks hasil analisis MDS. Analisis ini digunakan untuk memahami: (i) kesalahan dalam pembuatan skor di setiap atribut, (ii) ragam pemberian skor akibat perbedaan opini, (iii) kestabilan proses analisis yang dilakukan berulang, dan (iv) kesalahan pemasukan data (Thamrin et al., 2007).

\section{HASIL DAN PEMBAHASAN}

\section{Status Keberlanjutan Dimensi Ekologi}

Atribut keberlanjutan yang digunakan pada dimensi ekologi diantaranya: status kepemilikan lahan pertanian, intensitas konversi lahan pertanian, produktifitas komoditas tembakau Besuki Na-Oogst, penurunan kualitas tanah di lahan pertanian tembakau Besuki Na-Oogst, intensitas penggunaan pestisida, frekuensi kejadian bencana banjir di lahan pertanian tembakau Besuki Na-Oogst.

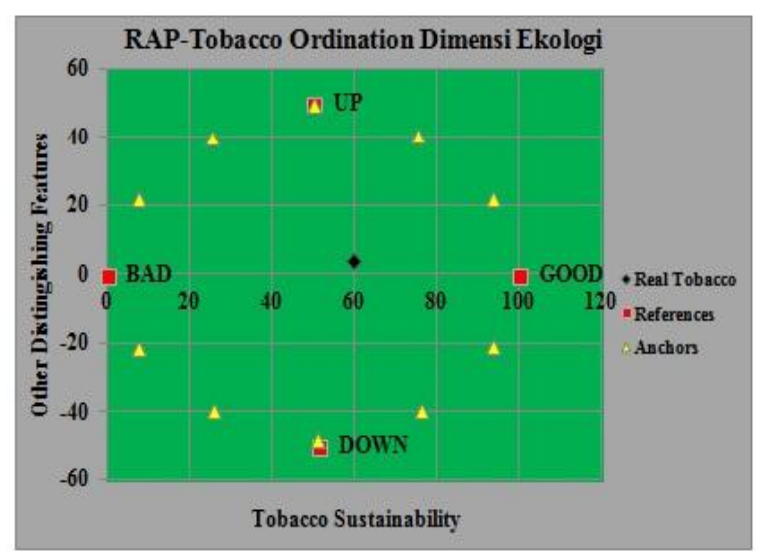

Figure 1. Sustainability Status Index of the Besuki Na-Oogst Tobacco commodity in Wuluhan District, Jember Regency based on Ecological Dimensions

Berdasarkan Figure 1. menunjukkan hasil analisis dari ordinasi Rap-Tobacco pada dimensi ekologi diperoleh nilai indeks status keberlanjutan komoditas tembakau Besuki Na-Oogst di Kecamatan Wuluhan Kabupaten Jember adalah sebesar 59,82. Nilai tersebut menunjukkan status keberlanjutan komoditas tembakau Besuki $\mathrm{Na}$ Oogst berada pada posisi skala ordinasi antara 50,01 - 75,00 dan berada pada dimensi ekologi berada pada status cukup berkelanjutan.

Hasil dari analisis leverage attributes atau atribut sensitif pada dimensi ekologi yang memiliki nilai RMS (Root mean Square) $\geq 2 \%$ yaitu, status kepemilikan lahan pertanian sebesar RMS 2,58\% (Figure 2). Atribut sensitif merupakan atribut yang berperan bagi status keberlanjutan pada dimensi yang akan dikaji, dimana atribut ini mampu mendorong dan menghambat status keberlanjutan dari komoditas 
tembakau Besuki Na-Oogst pada dimensi ekologi. Atribut sensitif bisa dilihat dari nilai Root mean Square (RMS), apabila nilai RMS $\geq 2 \%$ maka atribut tersebut masuk dalam kategori sensitif (Lestari et al., 2015).

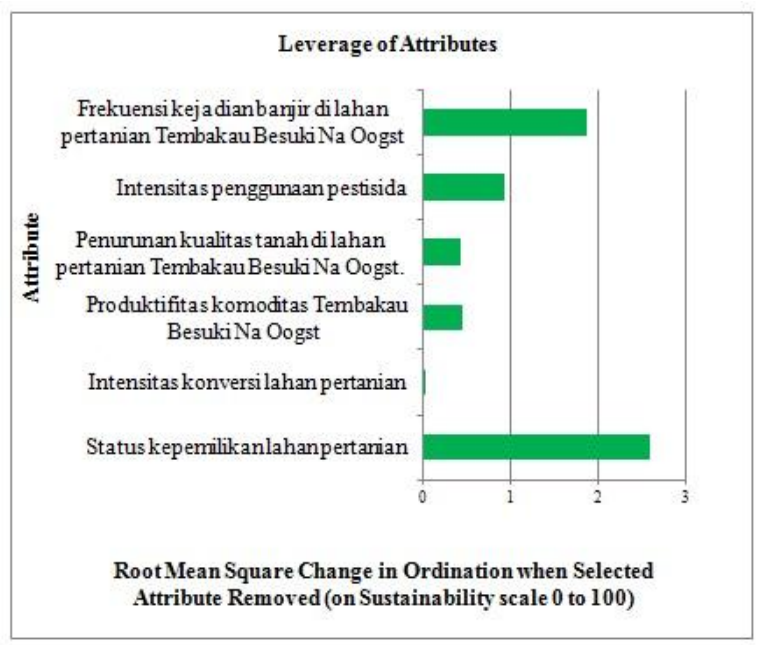

Figure 2. Leverage analysis of Besuki Na-Oogst Tobacco in Wuluhan District, Jember Regency based on Ecological Dimensions

Status kepemilikan lahan pertanian petani tembakau Besuki Na-Oogst di Kecamatan Wuluhan Kabupaten Jember di bagi menjadi 4, antara lain petani yang meyewa lahan milik orang lain; petani dengan lahan pertanian milik sendiri; petani yang menggarap lahan milik orang lain; dan petani yang menyewa dan penggarap lahan pertanian milik orang lain. Status kepemilikan lahan pertanian petani tembakau Besuki Na-Oogst di Kecamatan Wuluhan Kabupaten Jember sebagian besar milik sendiri. Petani dengan lahan pertanian milik sendiri merupakan petani yang memiliki potensi untuk memperhatikan dimensi keberlanjutan dalam berusahatani tembakau Besuki Na-Oogst, karena petani yang mempunyai lahan pertanian sendiri lebih mengutamakan produksi tetapi juga akan berpotensi memperhatikan status keberlanjutan tembakau Besuki Na-Oogst. Keadaan seperti ini dapat mendorong status keberlanjutan dari komoditas tembakau Besuki Na-Oogst.

Keberlanjutan ekologis merupakan suatu keberlanjutan yang menjamin eksistensi bumi. Untuk mencapai keberlanjutan ekologis integritas tatanan lingkungan harus dijaga dan dilestarikan melalui upaya peningkatan daya dukung dan melakukan pemanfaatan sumberdaya yang dapat dipulihkan dalam menjamin keberlanjutan ekologis (An-Naf, 2005). Selain itu untuk mendukung keberlanjutan ekologi pentingnya untuk menerapkan pajak lingkungan untuk menjadi konstrain bagi pelaku usaha disektor agroindustri termasuk komoditas tembakau Besuki Na-Oogst (Diartho, 2017).

\section{Status Keberlanjutan Ekonomi}

Atribut keberlanjutan yang digunakan dalam dimensi ekonomi, antara lain tempat menjual hasil panen tembakau Besuki Na-Oogst; harga komoditas tembakau Besuki Na-Oogst; wilayah pemasaran hasil olahan komoditas tembakau Besuki Na-Oogst; keuntungan usahatani tembakau Besuki Na-Oogst; kontribusi tembakau Besuki Na-Oogst terhadap Product Domestic Regional Bruto (PDRB); dan sarana pendukung untuk menjalankan usahatani tembakau Besuki Na-Oogst.

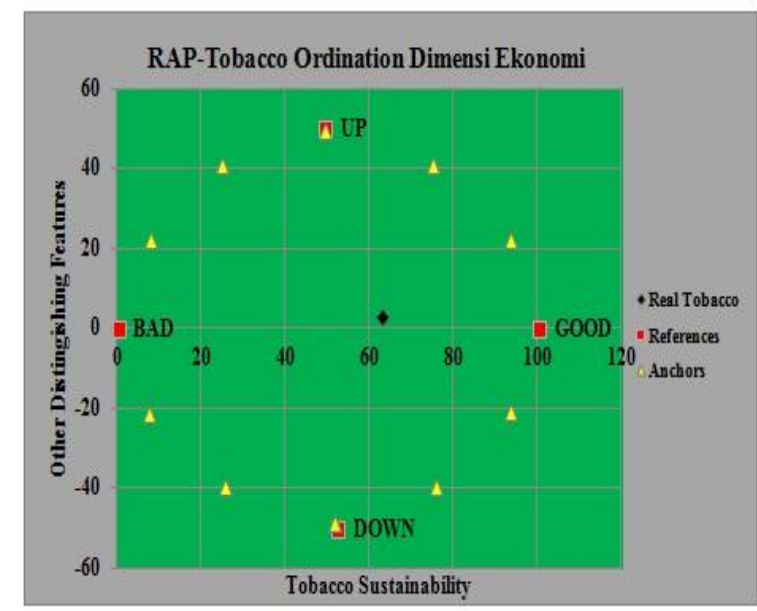

Figure 3. Sustainability Status Index of the Besuki Na-Oogst Tobacco commodity in the District Wuluhan Kabupaten Jember based on Economic Dimensions

Berdasarkan Figure 3. menunjukkan hasil dari analisis ordinasi Rap-Tobacco pada dimensi ekonomi nilai indeks status keberlanjutan komoditas tembakau Besuki Na-Oogst di Kecamatan Wuluhan Kabupaten Jember adalah sebesar 63,05. Nilai tersebut menunjukkan bahwa status keberlanjutan komoditas tembakau Besuki $\mathrm{Na}$-Oogst berada pada posisis skala ordinasi antara 50,01 - 75,00 dan status keberlanjutan komoditas tembakau Besuki Na-Oogst di Kecamatan Wuluhan Kabupaten Jember pada 
dimensi ekonomi berada pada status cukup berkelanjutan.

Hasil dari analisis leverage attributes atau atribut sensitif pada dimensi ekologi yang memiliki nilai RMS (Root mean Square) $\geq 2 \%$ yaitu, harga komoditas tembakau Besuki $\mathrm{Na}$ Oogst sebesar RMS 5,16\%, wilayah pemasaran hasil olahan komoditas tembakau Besuki $\mathrm{Na}$ Oogst sebesar RMS $\geq 6,73 \%$, tempat menjual hasil panen tembakau Besuki Na-Oogst sebesar RMS $\geq 2,45 \%$, dan sarana pendukung untuk menjalankan usahatani tembakau Besuki $\mathrm{Na}$ Oogst RMS $\geq 2,24 \%$. Pada dimensi ekonomi atribut sensitif yang memiliki nilai RMS terbesar adalah atribut wilayah pemasaran hasil olahan komoditas tembakau Besuki Na-Oogst dengan nilai RMS sebesar $\geq 6,73 \%$ (Figure 4). Wilayah pemasaran hasil olahan komoditas tembakau Besuki Na-Oogst di Kecamatan Wuluhan Kabupaten Jember saat ini sebagian besar dijual di luar negeri dengan begitu ekspor komoditas tembakau Besuki Na-Oogst masih terus berjalan berarti masih terdapat permintaan akan komoditas tembakau Besuki Na-Oogst. Keadaan ini juga sangat mendorong akan status keberlanjutan komoditas tembakau Besuki Na-Oogst di Kecamatan Wuluhan Kabupaten Jember.

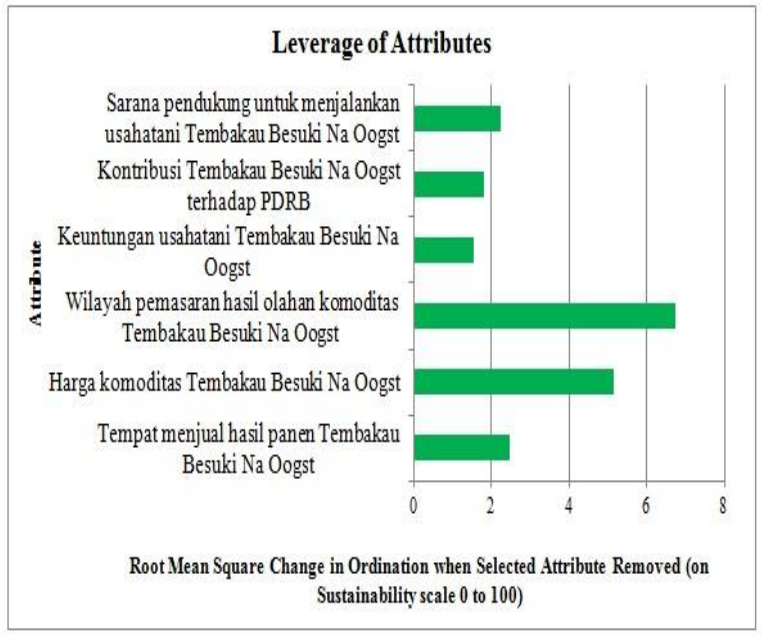

Figure 4. Commodity leverage analysis of Besuki Na-Oogst Tobacco in Wuluhan District Jember Regency is based on Economic Dimensions.

Keberlanjutan ekonomi merupakan suatu keberlanjutan yang menjamin kemajuan ekonomi secara berkelanjutan dan mendorong efisiensi ekonomi. Terdapat tiga unsur untuk mencapai keberlanjutan ekonomi yaitu efisiensi ekonomi, kesejahteraan ekonomi yang berkesinambungan, serta meningkatkan kemakmuran dan distribusi kemakmuran masyarakat (An-Naf, 2005). Lebih lanjut Diartho (2017) menjelaskan untuk pengembangan sektor ekonomi berbasis pada sektor unggulan pertanian di kawasan perdesaan penting melibatkan kelembagaan BUMDes sebagai aktor penggerak ekonomi lokal.

\section{Status Keberlanjutan Sosial}

Atribut keberlanjutan yang digunakan dalam dimensi soasial, diantaranya tingkat penyerapan tenaga kerja, pengetahuan tentang usahatani komoditas tembakau Besuki Na-Oogst berkelanjutan, eksistensi petani tembakau Besuki $\mathrm{Na-Oogst}$, pengaruh tembakau Besuki Na-Oogst kepada nilai sosial budaya masyarakat, tingkat pendidikan formal terakhir petani, persepsi petani tentang komoditas tembakau Besuki Na-Oogst yang berkelanjutan.

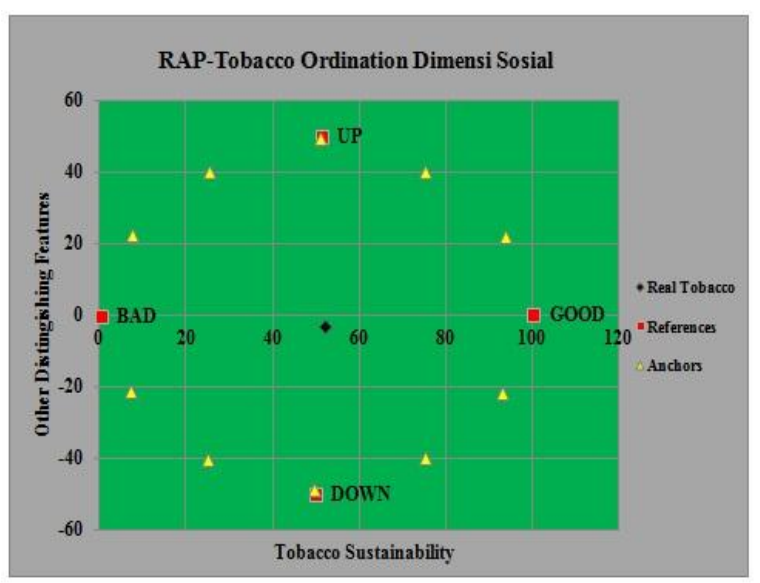

Figure 5. Sustainability Status Index of Besuki Na-Oogst Tobacco commodities in Wuluhan District, Jember Regency based on Social Dimensions

Berdasarkan Figure 5. menunjukkan hasil dari analisis ordinasi Rap-Tobacco pada dimensi sosial diperoleh nilai indeks status keberlanjutan komoditas tembakau Besuki Na-Oogst di Kecamatan Wuluhan Kabupaten Jember adalah sebesar 51,93. Nilai tersebut menunjukkan bahwa status keberlanjutan komoditas tembakau Besuki $\mathrm{Na}$-Oogst yang berada pada posisis skala ordinasi antara 50,01 - 75,00 dan status keberlanjutan komoditas tembakau Besuki Na-Oogst di Kecamatan Wuluhan Kabupaten Jember pada dimensi sosial berada pada status cukup berkelanjutan. 
Hasil dari analisis leverage attributes atau atribut sensitif pada dimensi sosial yang memiliki nilai $\mathrm{RMS} \geq 2 \%$ yaitu, pengetahuan tentang usahatani komoditas tembakau Besuki Na-Oogst berkelanjutan sebesar RMS 2,79\%, eksistensi Petani tembakau Besuki Na-Oogst sebesar RMS $\geq 3,72 \%$ dan pengaruh tembakau Besuki $\mathrm{Na}$ Oogst terhadap nilai sosial budaya masyarakat sebesar RMS 6,11\%. Pada dimensi ekonomi atribut sensitif yang memiliki nilai RMS terbesar adalah pengaruh tembakau Besuki Na-Oogst terhadap nilai sosial budaya masyarakat dengan nilai RMS sebesar 6,11\% (Figure 6).

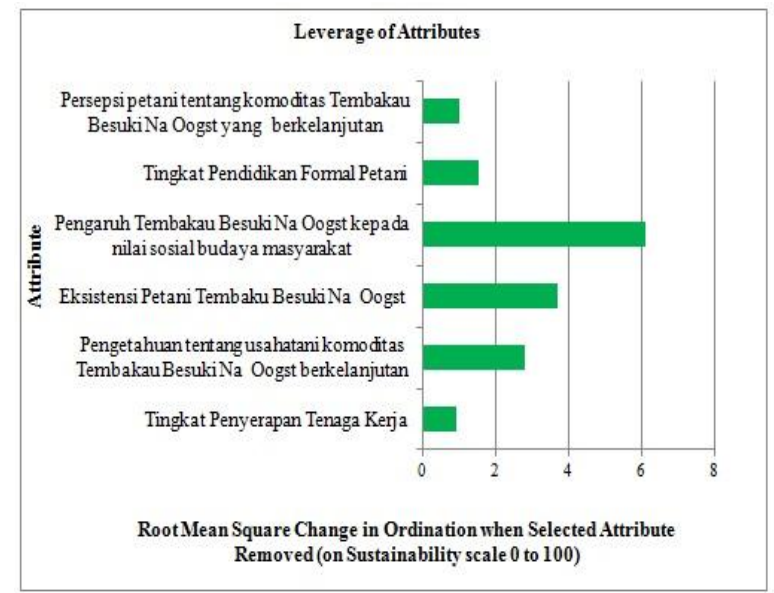

Figure 6. Commodity leverage analysis of Besuki Na-Oogst Tobacco in Wuluhan District, Jember Regency based on Social Dimension

Dampak dari Pengaruh tembakau Besuki $\mathrm{Na}$ Oogst kepada nilai sosial budaya masyarakat cukup positif. Hal ini bisa dilihat dari masih ada yang menanam hingga menggunakan produk hasil olahan tembakau Besuki Na-Oogst meskipun tidak semuanya yang menggunakan produk hasil olahan tembakau Besuki Na-Oogst hanya minoritas. Keadaan seperti ini sangat mendorong akan status keberlanjutan komoditas Tembakau Besuki Na-Oogst di Kecamatan Wuluhan Kabupaten Jember.

Dimensi sosial, merupakan suatu orientasi kerakyatan yang berkaitan dengan kebutuhan akan kesejahteraan sosial yang dicerminkan oleh kehidupan sosial yang harmonis (termasuk tercegahnya konflik sosial), reservasi keragaman budaya dan modal sosio-kebudayaan, termasuk perlindungan terhadap suku minoritas. Untuk itu, pengentasan kemiskinan, pemerataan kesempatan berusaha dan pendapatan, partisipasi sosial politik dan stabilitas sosial budaya merupakan indikatorindikator penting yang perlu dipertimbangkan dalam pelaksanaan pembangunan (Rivai dan Anugrah, 2011). Menurut James Midgley kesejahteraan sosial merupakan suatu keadaan atau kondisi kehidupan manusia yang tercipta ketika berbagai permasalahan sosial dapat dikelola dengan baik, ketika kebutuhan manusia dapat terpenuhi dan ketika kesempatan sosial dapat dimaksimalisasikan (Yahaya et al., 2017).

Menurut Susanto dan Widayati (2018) kualitas hidup petani tembakau dalam perspektif keperawatan pertanian merupakan hal yang juga sangat diperlukan dalam kehidupan sosial terutama dalam hal kondisi lingkungan yang digambarkan sebagai kemudahan transportasi, keterjangkauan fasilitas pelayanan kesehatan, lingkungan yang aman dan efek penyimpanan tembakau selama musim panen. Hal tersebut sangat dibutuhkan untuk menunjang produktivitas tenaga kerja yang nanti juga akan berdampak keberlanjutan Tembakau Besuki Na-Oogst.

Setelah nilai indeks status keberlanjutan di masing-masing dimensi yaitu, dimensi ekologi, ekonomi, dan sosial telah diketahui maka nilai indeks status keberlanjutan tersebut dapat di gambarkan pada Figure 7. diagram layang.

Diagram Layang-layang

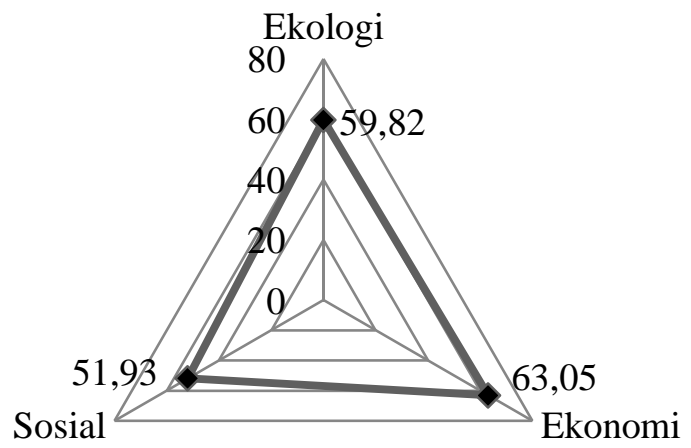

Figure 7. Sustainability Index Value with Kite
Diagram

Berdasarkan Figure 7. hasil analisis secara multidimensi menunjukkan bahwa status keberlanjutan komoditas tembakau Besuki $\mathrm{Na}$ Oogst berada pada status cukup berkelanjutan dengan nilai indeks status keberlanjutan sebesar 58,27 , Nilai tesebut berada pada skala ordinasi 50,01-75,00. Peningkatan status keberlanjutan dapat ditingkatkan dengan melakukan perbaikan pada atribut sensitif yang memiliki nilai Root 
mean Square yang tertinggi pada masing-masing dimensi.

Pada dimensi ekologi atribut sensitif yang memiliki nilai Root mean Square terbesar adalah status kepemilikan lahan pertanian petani tembakau Besuki Na-Oogst di Kecamatan Wuluhan Kabupaten Jember dengan nilai Root mean Square sebesar 2,55\%. Perbaikan yang dapat dilakukan pemberian pelatihan dan pembinaan bagi petani yang menyewa dan penggarap lahan pertanian milik orang lain serta yang memiliki lahan pertanian sendiri agar juga mengutamakan dan memperhatikan tentang dimensi keberlanjutan tembakau Besuki $\mathrm{Na}$ Oogst, disamping dengan mengutamakan produksi dalam jangka pendek.

Pada dimensi ekonomi atribut sensitif yang memiliki nilai Root mean Square terbesar adalah atribut wilayah pemasaran hasil olahan komoditas tembakau Besuki Na-Oogst dengan nilai Root mean Square sebesar $\geq 6,73 \%$. Perbaikan yang perlu dilakukan adalah melakukan evaluasi terhadap wilayah pemasaran dan diversifikasi hasil olahan tembakau tembakau Besuki $\mathrm{Na}$ Oogst hal ini dilakukan untuk menyesuaikan regulasi tentang pengendalian tembakau Framework Convention on Tobacco Control (FCTC) yang digagas oleh World Health Organization (WHO) sebagai badan kesehatan dunia.

Pada dimensi sosial atribut sensitif yang memiliki nilai Root mean Square terbesar adalah pengaruh tembakau Besuki Na-Oogst terhadap nilai sosial budaya masyarakat dengan nilai Root mean Square sebesar 6,11\%. Perbaikan yang dapat dilakukan adalah lebih mencintai dan menjaga serta melestarikan icon Kabupaten Jember yang berupa hasil olahan tembakau Besuki Na-Oogst atau cerutu seta melakukan diversifikasi tembakau Besuki Na-Oogst menjadi bahan olahan lainnya selain menjadi cerutu.

\section{KESIMPULAN}

\section{Kesimpulan}

Hasil dari identifikasi status keberlanjutan tembakau Besuki Na-Oogst di Kecamatan Wuluhan Kabupaten Jember secara multidimensi termasuk dalam kategori cukup berkelanjutan. Dimensi yang paling berpengaruh terhadap status keberlanjutan komoditas tembakau Besuki $\mathrm{Na}$ Oogst yaitu dimensi ekonomi, jika dibandingkan dengan dimensi ekologi dan sosial. Dimensi ekonomi memiliki nilai indeks keberlanjutan yang paling tinggi dan memiliki peluang besar dalam peningkatan status keberlanjutan komoditas tembakau Besuki Na-Oogst untuk kedepannya.

\section{Saran}

Untuk mempertahankan dan meningkatkan status keberlanjutan komoditas tembakau Besuki Na-Oogst ke depan, perlu dilakukan intervensi (perbaikan) terhadap atribut dimensi yang berpengaruh terhadap peningkatan status keberlanjutan komoditas tembakau Besuki $\mathrm{Na}$ Oogst dan perlu diprioritaskan perbaikan atribut pada dimensi keberlanjutan yang mempunyai nilai indeks keberlanjutan yang lebih rendah, yaitu dimensi ekologi dan sosial. Sedangkan, dimensi ekonomi berdasarkan kondisi existing, nilai indeks keberlanjutannya ke depan dapat dipertahankan atau lebih ditingkatkan.

Perbaikan terhadap atribut-atribut sebaiknya tidak hanya dilakukan pada atribut yang sensitif yang berpengaruh terhadap peningkatan status keberlanjutan, tetapi juga atribut-atribut yang tidak sensitif, agar status keberlanjutan komoditas tembakau Besuki Na-Oogst dapat ditingkatkan mendekati nilai indeks keberlanjutan $100 \%$. Tentunya dengan pertimbangan kemampuan finansial, waktu dan tenaga.

\section{DAFTAR PUSTAKA}

An-Naf, J. 2005. Pembangunan Berkelanjutan Dan Relevansinya Untuk Indonesia. Jurnal FISIP : MADANI, 2(2), 46-55. Retrieved from http://www.ejournal-

unisma.net/ojs/index.php/madani/article/view/ 171

BADAN PUSAT STATISTIK KABUPATEN JEMBER, [BPS]. 2013. Kabupaten Jember Dalam Angka. Jember. Retrieved from https://jemberkab.bps.go.id/publication/downl oad.html?nrbvfeve=ODljMjliMzlmZmZkNGI 4MzBjNDE1MDc4\&xzmn=aHR0cHM6Ly9q ZW1iZXJrYWIuYnBzLmdvLmlkL3B1Ymxp Y2F0aW9uLzIwMTMvMTIvMDUvODljMjli MzlmZmZkNGI4MzBjNDE1MDc4L2thYnV wYXRlbi1qZW1iZXItZGFsYW0tYW5na2Et MjAxMy5odG1s\&t

BADAN PUSAT STATISTIK KABUPATEN JEMBER, [BPS]. 2014. Kabupaten Jember Dalam Angka. Jember. Retrieved from https://jemberkab.bps.go.id/publication/downl 
oad.html?nrbvfeve=ODkzN2JmYjcyYjU5Zj M5MjEzODMyNTFI\&xzmn=aHR0cHM6Ly 9qZW1iZXJrYWIuYnBzLmdvLmlkL3B1Ym xpY2F0aW9uLzIwMTYvMDEvMjIvODkzN 2JmYjcyYjU5ZjM5MjEzODMyNTFIL2thYn VwYXRlbi1qZW1iZXItZGFsYW0tYW5na2 EtMjAxNC5odG1s\&t

BADAN PUSAT STATISTIK KABUPATEN JEMBER, [BPS]. 2015. Kabupaten Jember Dalam Angka. Jember. Retrieved from chrome-

extension://oemmndcbldboiebfnladdacbdfma dadm/https://jemberkab.bps.go.id/publication/ download.html?nrbvfeve=YTU2MzE3MDA2 N2Q2ZWRhMDg0YWI5NTMy\&xzmn=aHR 0cHM6Ly9qZW1iZXJrYWIuYnBzLmdvLml kL3B1YmxpY2F0aW9uLzIwMTYvMDEvM jIvYTU2MzE3MDA2N2Q2ZWRhMDg0YW I5NTMyL2

BADAN PUSAT STATISTIK KABUPATEN JEMBER, [BPS]. 2016. Kabupaten Jember Dalam Angka. Jember. Retrieved from chrome-

extension://oemmndcbldboiebfnladdacbdfma dadm/https://jemberkab.bps.go.id/publication/ download.html?nrbvfeve=M2ExNjQ2YjBm MTliN2I4MjU3MDkwMThj\&xzmn=aHR0c HM6Ly9qZW1iZXJrYWIuYnBzLmdvLmlk L3B1YmxpY2F0aW9uLzIwMTYvMDcvMT UvM2ExNjQ2YjBmMTliN2I4MjU3MDkw MThjL2

Diartho, H. C. 2017. Strategi Terhadap Pengembangan Kelembagaan BUMDESA di Kabupaten Jember. Ekonomikawan: Jurnal Ilmu Ekonomi Dan Studi Pembangunan, 17(2), 200-218.

https://doi.org/10.30596/ekonomikawan.v17i 2.1801

Djajadi, D. 2015. Tobacco Diversity in Indonesia : A review. Journal of Biological Researches, 20(27-32), 20-27. Retrieved from http://berkalahayati.org/files/journals/1/article s/851/submission/851-2416-1-SM.pdf

Fauzi, A. 2004. Ekonomi sumber daya alam dan lingkungan: teori dan aplikasi. Jakarta: PT. Gramedia Pustaka Utama. Retrieved from https://books.google.co.id/books?id=-e7BdK$\mathrm{gC} 40 \mathrm{C} \&$ printsec $=$ frontcover $\& \mathrm{hl}=\mathrm{id} \&$ source $=$ gbs_ge_summary_r\&cad $=0 \# \mathrm{v}=$ onepage $\& \mathrm{q} \& \mathrm{f}$ $=$ false
Kavanagh, P., \& Pitcher, T. J. 2004. Implementing Microsoft Excel Software For Rapfish: A Technique For The Rapid Appraisal of Fisheries Status. Fisheries Centre Research Reports, 12(2), 2-75. Retrieved from https://open.library.ubc.ca/media/download/p $\mathrm{df} / 52383 / 1.0074801 / 1$

Lestari, rma D., Hapsari, T. D., \& Ridjal, J. A. 2015. Kajian Persediaan Bahan Baku Dan Keberlanjutan Agroindustri Tape Dikabupaten Jember. Berkala Ilmiah PERTANIAN, 2(1), 1$10 . \quad$ Retrieved from http://repository.unej.ac.id/bitstream/handle/1 23456789/70994/IRMA DWI LESTARI.pdf?sequence $=1 \% 0 \mathrm{~A}$

Pratama, A. L. Y., Soetriono, S., \& Januar, J. 2018. The Farm Risk Management Of Besuki Na-Oogst Tobacco In Tanjungrejo Village, Jember Regency. Agricultural Social Economic Journal, 18(1), 13-22. https://doi.org/10.21776/ub.agrise.2018.018.1 .3

Qoriah, C. G., \& Meliczek, H. 2006. Supply Response and Competitiveness of Na-Oogst Tobacco Production Analysis in Jember Regency-Indonesia. In Tropentag "Prosperity and Poverty in a Globalised WorldChallenges for Agricultural Research" ( $\mathrm{p}$. 356). University of Bonn. Retrieved from http://www.tropentag.de/2006/proceedings/pr oceedings.pdf

Rahadian, A. H. 2016. Strategi Pembangunan Berkelanjutan. Prosiding Seminar STIAMI, 3(01), 46-56. Retrieved from http://www.stiami.ac.id/jurnal/detail_jurnal/3 4/140-strategi-pembangunanberkelanjutan.html

Rivai, R. S., \& Anugrah, I. S. 2011. Konsep dan Implementasi Pembangunan Pertanian Berkelanjutan di Indonesia. Forum Penelitian Agro Ekonomi, 29(1), 13-25. https://doi.org/10.21082/fae.v29n1.2011.1325

Santoso, K. 2013. Tembakau: dibutuhkan dan dimusuhi. Jember: Jember University Press. Retrieved from http://repository.unej.ac.id/handle/123456789 $/ 62970$

Sari, O. A., Kuntadi, E. B., \& Widjayanthi, L. 
2017. Dampak Erupsi Gunung Api Raung Terhadap Usahatani Tembakau Na-Oogst Di Desa Ampel Kecamatan Wuluhan Kabupaten Jember. Jurnal Agribest, 1(2), 180-186. https://doi.org/10.32528/AGRIBEST.V1I2.11 56

Susanto, T., \& Widayati, N. 2018. Quality of life of elderly tobacco farmers in the perspective of agricultural nursing: a qualitative study. Working with Older People. https://doi.org/10.1108/WWOP-01-20180002

Suyana, J., Sinukaban, N., Sanim, B., \& Purwanto, M. Y. J. 2010. Profil Usaha Tani Lahan Kering Berbasis Tembakau Di Sub-Das Progo Hulu (Kabupaten Temanggung, Jawa Tengah). Caraka Tani: Journal of Sustainable Agriculture, 25(2), https://doi.org/10.20961/carakatani.v25i2.140 58

Thamrin, Sutjahjo, S. H., Herison, C., \& Sabiham, S. 2007. Analisis keberlanjutan wilayah perbatasan Kalimantan Barat-Malaysia untuk pengembangan kawasan agropolitan (Studi kasus kecamatan dekat perbatasan Kabupaten Bengkayang). Jurnal Agro Ekonomi, 25(2), 103-124.

https://doi.org/10.21082/jae.v25n2.2007.103124

Yahaya, M. H., Badaruddin, R. F. R., \& Singh, P. S. J. 2017. Kesejahteraan Sosial dan Perumahan. SOSIOHUMANIKA, 10(2), 245256. Retrieved from http://www.mindamasjournals.com/index.php/sosiohumanika/article /view/923 